\section{O PROBLEMA DA ELABORAÇÃO LEGISLATIVA}

\section{Rosah Russomano de Mendonça Lima}

Professôra de Direito Constitucional da Faculdade de Direito de Pelotas (Universidade R. G. do Sul).

"O trabalho jurídico é daqueles que exigem o máximo de paciência e de imparcialidade. Estudar duma maneira aprofundada os movimentos dos usos e e da jurispmudência, os resultados efetivos das legislações estrangeiras, reunir e interpretar os dados da estatística, é um trabalho científico e técnico. Nenhuma intuição nêle pode ter lugar.

$O$ que fês o alto valor do Código Civil francês é que foi quase todo obra de juristas. profissionais procurando resumir, sem intuitos políticos reservados, o direito vivido, o direito histórico, o direito nacional do seu pars".

\section{JEAN CRUET}

("A vida do Direito", pg. 327).

Uma das mais belas conquistas da humanidade foi, indubitàvelmente, aquela que, à absorção dos poderes nas mãos de um só soberano, fêz suceder o seu desligamento, a sua tri-partição, destruindo o despotismo e decortinando, para todos os cidadãos, novos e amplosin horizontes de garantia e tranqüilidade.

O monarca absoluto, que possuía suas prerrogativas ilimitadas, pela propriedade com que legislava, executava as leis e as aplicava, exercendo essas atividades como se exercesse atributos inerentes à sua personalidade, aquêle monarca absoluto assistiu, perplexo, ao desprendimento, de seu próprio eu, de funçôes que passaram a reclamar órgãos próprios e independentes.
O evolver dos acontecimentos demonstrou, de modo categórico, a impossibilidade de reduzir, como dantes, as exigências da vida a fórmulas simplistas e, desde essa época, a divisão dos Poderes do Estado em Legislativo, Executivo e Judiciário passou a ser uma realidade axiomática e promissora, funcionando todos num perfeito entrosamento de equilíbrio e de acôrdo com as regras fundamentais de independência. No entanto, não em consonância com essa independência rígida, inflexível, que poderia ser um obstáculo, antes que um auxílio, aos objetivos da soberania; mas, sim, segundo uma independência dúctil, racional, que permite, em momentos de exceção, a intromissão de um poder na esfera de atividade do outro, para evitar demasias e arbitrariedades, realizando a teoria célebre dos "checks and balances".

Cada um dêsses Poderes, porém, - o Legislativo, o Executivo e o Judiciário - que dispõem de órgãos específicos, para o desempenho de suas funções; que as norteiam no intuito de satisfazer os altos interêsses da coletividade; que possuem uma capacidade de ação característica, não prestando contas uns aos outros, salvo quando permitidos os contractos constitucionais; cada um dêsses Poderes encarna, pelo resultado conjugado de seus trabalhos individuais, a própria soberania nacional. Não se sobrepõem, assim, mùtuamente, em importância, nem se encontram em planos desiguais.

Se, no entanto, não há supremacia de um, em relação aos demais, não se pode negar, em face das realidades sociais e dos problemas que se vão desdobrando, a importância crescente da função legislativa, tanto que o insigne PONTES DE MIRANDA, depois de assegurar: "Quem faz a lei é ıque é o mestre da vida social", acentua, ainda, que: "Os movimentos reformistas e revolucionários, quaisquer que sejam a sua natureza, os seus propósitos e as suas táticas, sem nos dizeres e, talvez, sem terem nítida consciência daquilo por que lutam, o que querem é, sòmente, chamar a si a feitura das leis". "(Comentários à Constituição Federal de 1.946, vol. II, pg. 7).

Nesses últimos decênios, tem-se procurado encontrar, no cáos de tumultuosos acontecimentos, o meio mais apropriado, para resolver o problema da legislação. E, ante a infinidade de soluções apresentadas - muitas delas perfeitas, sob o ponto de vista teórico, mas inexeqüíveis, ante as realidades sociais de certos Estados —, é ainda o ilustre PONTES DE MIRANDA quem executa uma síntese das mesmas, apontando, por exemplo, as que transferem, ao Executivo, parte da deliberação das leis; ao que introduzem práticas de democracia semidireta, por meio do referendum e da iniciativa popular; as que optam pela exclusiva representação econômica; as que preferem a existência das representações profissional e democrática em câmaras diferentes as que defendem a câmara única, constituída pelos deputados, eleitos 
pelo povo, e pelos grupos profissionais, etc. Esta última modalidade sem que a inovação conseguisse su vigência da Constituição de 1934, da progressiva por que passava rou o golpe de 10 qua queda geque o Parlamento de novembro de 1937, na confirmação histórica de que o Parlamento enfraquecido e desmoralizado abre caminho livre
ao despotismo e à ditadura.

E' imprescindível, pois, para a garantia dos cidadões e de todo - Estado, que o Poder Legislativo se mantenha conceituado e forte sem que se torne, porém, igualmente despótico, porque, talvez, de todos, o mais temível seja o despotismo das assembléias, de que fo exemplo o aluvião de sangue que a Revolução Francesa derramou em nome da Liberdade.

E, para a construção de um Legislativo que corresponda, fielmente, às aspirações da massa popular, para a edificação de um tôdas as teorias ventiladas, propostas e e guia a simples expressão - "the right tentadas, sirva de inspiração cuja aplicação the right man in the right place" vidas a tortuosos labirintos da São, neste sentido, categóricas as palavras de LAURENT, quan-
a diañães da vida social. do assegura que:

"S'il faut des hommes spéciaux pour appliquer les lois et les enseigner, à plus forte raison en faut-il pour les préparer"... ("Bel-
gique Judiciaire, pg. 737).

E, ainda, a afirmativa de JEAN CRUET:

"Se, a bem dizer, não existe uma ciência das leis, há, no entanto, a maneira científica de legislar".

- A expressão Parlamento teve, durante o desenrolar dos anos, acepções diversas. Inicialmente, designava, apenas, a palestra que os monges entretinham, nos cláustros, após a ceia. Passou, depois, indicar conferências de relêvo, entre pessoas de vulto, axempois, quela, que SIR COURTENAY II BERT e o Papa Inocêncio IV no realizada entre Luíx IX 1245. E, ainda posteriormente cia; mas, ainda Parlamento, não apenas as palestras de importância; mas, ainda, a reunião de pessoas, em assembléias nacionais, convocadas pelo monarca.

Daí por diante, o sentido da palavra em aprêço se foi restringindo e, hoje, é a mesma aplicada, usualmente, para designar ostringresso Nacional, formado por umar o Conhabitual passou a independer de convocac̃̃o cuja reunião se realizar, automàticamente, em se realizar, automàticamente, em épocas determinadas.
Gradativamente, através dos séculos, dilataram-se, em número e importância, as atribuições do Parlamento. O poder político do Parlamento inglês, por exemplo, dividido em duas Câmaras - a dos Comuns e a dos Lordes - , teve um grande desenvolvimento, durante os séculos 14 e 15, chegando a impor, em 1327, a renúncia de Eduardo II e, após, a de Ricardo II, resolvendo que, após sua deposição, ocuparia o trono Enrique de Lancaster. Êsse desenvolvimento, porém, como é natural, não se processou no mesmo diapasão, o que ocasionaria o despotismo parlamentar. Suas faculdades restringiram-se durante o século 15, para se dilatarem novamente depois, a ponto de Thomas Smith afirmar, no século 15, em obra de sua autoria, "que el poder más alto y absoluto del reino inglês era el Parlamento". Não obstante, a história nos mostra a sucessão de novas hostilidades, entre rei e Parlamento, predominando, sempre, um em detrimento de outro, ao sabor das épocas e das exigências da vida em sociedade.

O Parlamento, porém, encarando o Poder Legislativo, se foi firmando e crescendo em autoridade, não só pelas relevantes funções que desempenha, como porque, a exemplo dos sistemas que, como o nosso, adotam a bicameralidade, se representam, nêle, a nação inteira e todos os Estados da Federação.

$\mathrm{Na}$ linha ascensional da evolução política e jurídica, os períodos em que o Parlamento é eclipsado, pela supremacia do Executivo, sintetizam, apenas, as quedas bruscas, peculiares aos desequilíbrios transitórios.

Para que essas quedas, entretanto, não se processem demasiado seguidamente; para que o Parlamento se situe no plano que realmente lhe compete, como órgão da soberania nacional; para que seja alcançado, em tôda a sua essência, o supremo propósito de traçar as normas abstratas e coercitivas com técnica, tornando-as aplicáveis e realizáveis; para que se efetuem essas atribuições, na sua legítima significação, indispensável se torna que o Parlamento se integre de representantes dignos, honestos e, sobretudo, capazes.

Caso contrário, a Assembléia Nacional, em vez de se dignificar, cairá no polo oposto, desacreditando-se no conceito público, pela redação de regras imprecisas, falhas e incompletas.

Para que o Parlamento, assim, colime seus objetivos, deverá assentar sôbre a base sólida de uma representação tão perfeita, quanto o permitam as precárias condições do gênero humano.

Não se poderia, naturalmente, adotar o mesmo sistema de organização, para todos os Estados, porque nêles dịvergem as condições de ambiente, de sorte que o que triunfasse num determinado país poderia redundar em desastre incontestável, no seio de outra nação qualquer. 


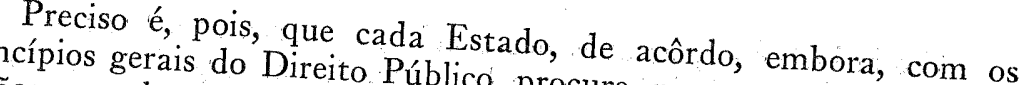
órgãos, aquela que melhor Público, procure, na estruturação de seus povo e que mais ràpidamente coadune com a mentalidade de seu

Em nosso país, onde desde

regime democrático, republicano e transformação de 1889 , impera o acolhendo o exemp duas Casas. Uma da maioria dos povos civilizados, se dividenal, representantes de tôda a Nac̃õor dos Deputados, se compóe de sufrágio universal e pela represon eleitos diretamente pelo povo de tra, o Senado Fresentação proporcional, enquanto, pelo eleitos também constituída pelos represental é cou - sistema majoritário. Enquanto sufrágio universal, mas segundo representantes da prim. Enquanto, por conseguinte, o número do decréscimo da res, que configuram os Estado vai representar, o número dos senadodades das variadas os Estados, é, sempre, fixo, em que pese às dispariextensão territorial, ou em impor administrativas, suas diferenças em

Assim, os comportância econômica e cultural. do povo, que os elege livremente Congresso Nacional sâo mandatários regra geral, a diretiva imprimida catando os cidadãos, nessa escolha, tencerem.

Os partidos políticos desempenham enorme importân expansão, do reconinão pública nacional. Dependendo esta, para sua igualmente, para seu desento dos princípios de liberdade, depende tido político, para seu desenvolvimento e coesão, da existência depende, um acôr mum, nas eleições dos govero de cidadãos, para procederem em coêstes exercerem". (Cus governantes, e na fiscalização do poder co-

Os partidos políticos, portanto Constitucional", vol. I, pg. 322). norteiam por uma orientação comum arregimentam prosélitos, que se imposta, muito embora, ção comum e que se submetem à disciplin ciplina racional, qua seu verdadeiro sentido, seja esta uma dis deixa a cada um dos filiado exige absurdos e que, concomitantemente, ou não se sujeitos filiados a faculdade de se submeter a seus ditames, ou não se sujeitar aos mesmos, podendo continuar neter a seus ditames,

E' a êsses sempre, se assim o desejar.

didatos às eleições. Conseqüentemente privilégio de apresentarem candidatos ao Congresso mesma forma, todos os indivíduos membros que os integram e, da momento das eleições, a favor de nomes incluídos nas chapas pertencentes às várias facçẽes.

Tem-se entendido que, assim, se evitam as surprêsas e se cerceia a impetuosidade demagógica, corolários fatais da confusão podítica.

O Brasil, em matéria político-eleitoral, tem, sem sombra de dúvida, nesses últimos anos, realizado inegáveis adiantamentos. Suprimiram-se os erros cometidos na época anterior a 1930, procurando evitar-se a ação sugestiva e quase interventiva do Presidente, no ParJamento, e destruindo-se as fraudes eleitorais, o sistema falso da verificação das eleições e do reconhecimento dos poderes pelos próprios corpos políticos.

O Código Eleitoral de 1932 transformou, bruscamente, o panorama e impulsionou, com fôrças novas, o entusiasmo da população. Não obstante, com o colapso havido em 1937-1945, perderam-se anos preciosos para a educação de nosso povo e, restaurados os partidos políticos não se tem conseguido, apesar de tudo, compensar aquela regressão e concretizar os legítimos anseios da coletividade.

No tocante à indicação de candidatos, que devem integrar o Parlamento, por exemplo, estamos longe de atingir uma condição satisfatória. Influências diversas se fundem, para dificultar a consecução dêsse desiderato. As vacilações do momento atual - empecilho que é denominador comum a todos os Estados - conjugam-se à precariedade de nossos meios, de nossa educação cívica e de nossa preparação política.

Assim, as agremiações partidárias, na seleção dos nomes que devem compor as respectivas chapas, antes de compulsar o valor verdadeiro de cada um, como homem de intelecto e de ação, verificam, principalmente, suas possibilidades eleitorais, elevando-se, numa sucessão de lamentáveis erros, pessoas incompetentes, se bem que probas e com louvável intento de acertar, às culminâncias de legislador, apenas porque contam com um número certo de votos. No nosso Estado do Rio Grande do Sul, v.g., onde é intensa a corrente imigratória alemã e italiana, são, seguidamente, incluídos nas listas partidárias descendentes daqueles imigrantes, ou que ostentem um nome de uma outra nacionalidade, sem que, muitas vêzes, os cidadãos, sôbre os quais recái tão alta deferência, sejam portadores, mesmo atenuadamente, dos atributos mínimos indispensáveis às importantes funções que lhes vão competir.

Noutras ocasiões, predomina, no seio de cada facção política, o desejo de premiar dedicações partidárias. E, mais um vez, relega-se a um plano inferior o mérito pessoal dos outros concorrentes.

Como conseqüência, a representação nacional, apesar de brilhantes exceções, é precária e falsenda, despertando a desconfiança das 
novas gerações, para com o Parlamento atual, e sua nostalgia, em relação ao que passou, a ponto da evocação de figuras exponenciais que integraram, digamos, a Constituinte de 1891, se realizar, sempre, num misto de sonho e de legenda...

Em todos os setores da vida social, a especialização de funçóes determina o aparecimento concomitante de pessoas que as desempenham de modo específico e que se denominam especialistas.

Não há muito tempo, um médico exercia todos os ramos da medicina, desde a clínica geral até a cirurgia. Com o decorrer dos anos, tais práticas se foram tornando obsoletas. O clínico não se imiscue nas complicadas técnicas cirúrgicas e todos os departamentos da ciência médica se acham cada vez mais estanques. Mesmo no nosso Estado, há oftalmologistas que só exercem sua especialidade, não atendendo os casos ligados à oto-rino-laringologia. E esta, a seu turno, em centros maiores, chega a se tripartir, sendo cada órgão alvo dos cuidados de um só indivíduo, que, demoradamente, se dedicou àquele estudo.

$\mathrm{E}$, assim, em todos os demais ramos do conhecimento humano.

Pois bem: justamente em relação à Sociologia, ciência que, na classificação de Comte, ocupa o ápice, pela sua complexidade, justamente em relação à mesma, qualquer pessoa se julga apta, capaz, competente.

Seria ridículo o leigo que, com certa intuição matemática, quisesse intrometer-se nos quefazeres de um engenheiro. Mas é justo e razoável que, em matéria de legislação, qualquer cidadão possa interferir; independentemente de suas qualidades...

HERBERT SPENCER, ante êsses óbices, gerais a todos os povos, demonstrava, no seu "L'individu contre l'E'tat", todos os "males causados pelas leis feitas sem o conhecimento da ciência social".

No legislador, sobretudo, em face de suas importantes atribuições, se precisa exigir uma série muito detalhada de requisitos. Deveriam escolher-se, pois, apenas aquêles que fôssem instruídos, que tivessem conhecimentos sociológicos e jurídicos, que se interessassem por problemas dessa natureza, de maneira pública e evidente, e que; ao mesmo tempo, soubessem adaptar suas teorias à realidade prática da existência.

Confirmando essa assertiva, assim se pronuncia AURELINO LEAL: "Não é que só possam ser legisladores os téoricos da sociologia. Ao contrário, penso que um cidadão, que só conheça as sociedades humanas através de princípios abstratos, será um detestável legislador. E' preciso que êle tenha uma cultura da ciência social e possua o poder de adaptar seus conhecimentos às capacidades e condições históricas do meio em que vive. Sem tais requisitos, não poderá ser um bom legislador". ("Teoria e Prática da Constituição" Federal Brasileira", pg. 220).

E são de CLERMONT TONNERRE as seguintes palavras sinceras, que valem como uma lição: "Se l'on me demande porquoi, membre le l'Assemblée Nationale et coopérateur de l'ouvrage, je n'ai bre le lassemblee Nationale tous les défauts qui me frappent aupoint aperçu dans le temps tous les defauts quicume éducation ne jourd'hui, ma réponse sera simple et fódigir les lois, fonction n'avait préparé à cette auguste fonction de redigir les lois, fonction pour laquelle Rousseau veulait une intelligente supérieure, qui ví toutes les passions des hommes et n'en éprouvât aucune; je me toutes les passions des homme me trompais, et il me manquait deux trompais de bonne foi, mais je me trompais, et cheres, le temps et la maître don les leçons sont
connaissanes des hommes".

Objetar-se-á, sem dúvida que, principalmente num país, como o nosso, de recente formação histórica, seria absurdo e irrealizável o. pretender organizar-se uma Assembléia de numerosos representantes, pretender organizar-se umalor onde todos apres todos os indivíduos, não só de pensamento como, do que isso, fôssen

Acrescentar-se-á, então, que o problema não é novo e que já está decidido, pelas comissões parlamentares, que são integradas, tanto quanto possível, por técnicos e especialistas.

A objec̃ão, no entanto, se verdadeira em princípio, não está resolvida, pela constituição das melhor realize a técnica de legiṣlar e que requer outra solução, que melhor realize a teccnica

traga novo impulso moralizador ao Parlamento.

As comissões parlamentares, aliás, estabeleceram-se, embora rudimentarmente a princípio, no século XVII, na lnglaterra, sob o reinado de Isabel. Começaram a nomear-se, então, pequenas comissónalque deveriam estudar certos projetos de lei e que se runiam habitualmente em Westminster. Quando as questões cresciam em importancia aumentava-se, também, o número dos componentes das mesmas.

Evolvendo através dos séculos, temos o seu regime atual que, consoante os moldes de nosso sistema constitucional, assegura, tanto quanto possível, a representação proporcional dos partidos ńnico, da que participem da respectiva Can

Constituição Federal de 1946).

Apesar dos progressos trazidos pela evolução, o sistema de comissões não satisfaz. Em primeiro lugar, porque seus membros, mui-

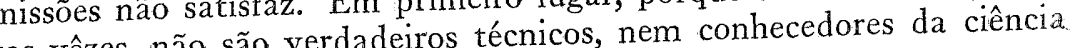
tas vêzes, não são verdadeiros tecnicos, nem conheces postos por apre-
social; mas, sim, representantes que ocupam êsses pol 
sentarem uma capacidade que assenta, exclusivamente, em mera presunção comum.

Em segundo lugar, as comissões, justamente por serem corpos menos numerosos, são mais passíveis de sofrer a pressão de interêsses particulares, que nem de leve se articulem com os interêsses da co-
letividade.

Já em sua obra - "O Govêrno pelo Congresso, à pg. 206" WOODROW WILSON, pronunciando-se sôbre o sistema vigente nos Estados-Unidos, assim escreveu:

"Sente o eleitor que a sua desconfiança para com o Congresso se autoriza com o que lhe consta de corrupto poder exercido, nos corredores da Câmara, por certos indivíduos (the lobbysts), em ajeitar a ação legislativa aos seus interêsses. Ouve de enormes subvençôes solicitadas e obtidas, pensões alcançadas mediante o valimento de agenciadores profissionais dessas mercês, consignações votadas a bem de contratadores desonestos, e não deixa de ter base, para concluir que êsses males são inerentes à própria natureza do Congresso; porque não há dúvida nenhuma que a fôrça do corretor parlamentar resulta, em boa parte, senão inteiramente, da facilidade, que the proporciona o sistema das Comissões. Está na ordem natural das coisas o abrirem-se-lhe os mais asados ensejos de tratar com as grandes Comissões que, na Câmara dos Representantes, mordomam o dinheiroInexeqüível lhe fôra manobrar os seus planos na vasta arena da Câmara inteira; mas, entre os membros das Comissões, encontra quantidades manipuláveis. Em conseguindo the dê ouvidos a Comissão, ou parte dela, pràticamente se apoderou da Câmara. Essa facilidade no acesso das Comissões a estranhos franqueia a influências ilegítimas fácil entrada em todos os ramós da legislação".

O sistema das Comissões, pois, não resolve, quanto às exigências da técnica legislativa, pela inclusão, nas mesmas, de elementos que não têm real conhecimento da ciência jurídica e, ainda, não resolve, sob o aspecto moral, pela corrução que propicia, em detrimento do prestígio e da independência do Poder Legislativo.

Uma pequena mudança, porém, na organização do Legislativc, poderia conduzir por melhores caminhos a técnica de legislar, caindo por terra as objeções que se levantam ao sistema das Comissões, sem que fôssem desvirtuados os moldes democráticos que se vêm dando à estrutura estatal.

No nosso Estado do Rio Grande do Sul, a Constituição CastiThista de 1891, compreendendo a insuficiểncia com que vinham sendo elaboradas as leis e as falhas de sua redação, rasgou novos rumos a elaboração legislativa.
A redação definitiva das leis, pois, que era, antes, obra de muitos, competindo a uma comissão do Congresso - que se haveria de ressentir, sempre, dos defeitos peculiares às Comissões - , passou a ser obra de um só indivíduo: o chefe do Estado.

Esse sistema, porém, ao par dos inconvenientes que se traduziriam pelas facilidades à hipertrofia do Executivo, acarreta outros, correspondentes à só existência de um redator final, como o que NESIO PINHEIRO distingue - "Em período de grande produção regislativa, um só indivíduo não pode acompanhar, com seu trabalho, mesmo que seja intensivo, a produção quantitativa dos atos".

Para que se não conceda, pois, tal prerrogativa ao Executivo apenas, fortalecendo-o em demasia; para que se não opere essa sobrecarga de afazeres, num só cidadão, preciso será que se outorgue tal concessão a um órgão coletivo.

Não, porém, ao órgão coletivo comum, representado pelo plenário do Parlamento, porque as dificuldades, então, se multiplicariam e se tornariam ainda mais complexas; mais, sim, a um órgão coletivo especial, que integrasse o Congresso Nacional, como o integram Câmara e Senado, e que fôsse composto, exclusivamente, de juristas, sociológos, economistas e filólogos, de reconhecido saber e proficiência, todos indicados e escolhidos, de comum acôrdo, pelo Parlamento, integrado de seus dois ramos, pelo Executivo e pelo Judiciário. $\mathrm{O}$ número de componentes dêsse novo órgão, naturalmente, seria muito menor do que aquêle que constitui a Câmara dos Deputados, devendo reservar-se algumas vagas, antes do preenchimento total, para serem ocupadas por especialistas indicados pelo próprio corpo técnico.

Substituindo o sistema de comissões, portanto, impor-se-ia êste outro, em que a uma agremiação científica seriam confiadas a revisão final e a redação dos projetos de lei.

A nova fórmula, em verdade, não encerraria novidade frisante, porquanto, estudando o ciclo constitucional francês, observaremos que, sob o domínio de Bonaparte, que nos deu a maravilha do Código Napoleônico, a Constituição Consular (1799) tripartia o Poder Legislativo, distribuindo-o em assembléias distintas: uma redigia as leis; outra as discutia e uma terceira as votava. Eram, respectivamente, o Conselho de Estado, o Tribunal e o Corpo Legislativo.

E, em nosso Estado do Rio Grande do Sul, BRUNO DE MENDONÇA LIMA, traçando o programa da antiga União Democrática Nacional, em 1933, consagrava, na parte votada à Organização Política, a existência de "órgãos coletivos técnicos, incumbidos de preparar os projetos de lei mais importantes, que devessem ser submetidos à aprovação dos representantes da Nação".

Reconhecem, pois, sociólogos e teóricos do Direito, a exemplo de WLLSON - citado, neste ponto, com entusiasmo, pelo gênio de 

RUY -, as deficiências da atual elaboração legislativa e os prejuízos.
acarretados pelo sistema das Comissões.

A solução indicada - extinção das Comissões e criação de um órgão, funcionando junto ao Legislativo, tendo e criaçao de um cípua a redação das leis — e er finalidade prevista técnico e sob o ponto de vista deca satisfaria, sob o ponto de

Não se lhe poderiam ar...

com a Constituicão Castilhista intuitos ditatoriais, como sucedeu rantida em tôda a sua plenitude 1891. Ficaria a democracia gauma agremiacão a sua plenitude, porquanto o novo instituto seria deliberação, que permaneceria técnica, sem o poder supremo de dos representantes daneceria pertencendo à órbita de competência dos representantes da nação. E não seria possivel que se acusassem seus componentes de possuir uma capacidade balôfa de fachada, de vez que a escoina dos mesmos, para integrar a distinguida agremias obedeceria a um real, desapaixonado, rigoroso e consciente progresso.
de seleção.

SIR COURTENAY ILBERT, estudando o Parlamento Inglês, acentua que: "As faculdades da Câmara dos Comuns podem ser divididas em três categorias: legislativa, financeiras e críticas". (FI Parlamento su historia, constitucion y práctica", pg .50).

Essas faculdades, no cenário brasileiro, se compreendem no âm. bito de ação das duas Casas do Parlamento, ora agindo separada As ativindo de maneira conjunta

consubstanciam criticas, nas quais se incluem as políticas e qne se putados, para iniciar., na competência privativa da Câmara dos Dequando não forem a tomada de contas do Presidente da República constitucional; para declarar as dentro do prazo exigido pelo texto sação contra o Presidente a procedência ou improcedência da acudade, e contra os Ministro da República, nos crimes de responsabilicrimes praticados críticas, que se traduzem, igualmentemo da nação; essas atividades privativa do Senado, para, na competência o "impeachment" de pertencer à esfera peculiar à Câma da República, não deixariam vesse interferência do novo órãa âmara e ao Senado, sem que houfinal das leis.

casos, a ação do citado corpo financeiras, já se faria sentir, em certos exemplo, como as demar corpo legislativo, porquanto o orçamento, por redação. como as demais leis, requer o concurso de ténicos, na sua

Por fim, quanto às atividades legislativas, pròpriamente ditas, sem resquício de dúvida, a ação daquela agremiação seria inequívoca e frisante, porquanto todo e qualquer projeto, sem importar de onde se originasse, pela iniciativa, seria redigido pelo conjunto de intelectuais especializados.

- A técnica da elaboração legislativa, consoante doutrina PONTES DE MIRANDA, se compõe de três elementos, que se podem representar: pela iniciativa, pelo exame e pela deliberacão ("Comentários à Constituição de 1.946, vol. II, pg. 7).

Fundindo-os, separando-os, mesclando-os em parte, as legislacões modernas têm conseguido uma variada amostra, em que se podem observar as mais diversas combinações.

Ora - a criação dêsse órgão, formado por especialistas de valor e renome, selecionados, cuidadosamente, pelos mandatários do povo, integrantes do Parlamento, pelo chefe do Estado, cuja investidura decorreu, também, da vontade expressa da nação, e pela serenidade imparcial do Poder Judiciário, a criação dêsse órgão quebraria o molde clássico entre nós adotado, imprimiria uma transformação radical na feitura das leis?

Assim seria se, por exemplo, só a êle coubesse a iniciativa de projetos de lei; se se lhe concedesse a prerrogativa de deliberar sôbre os mesmos; ou se se conjugassem ambas as faculdades, para lhas conceder.

Não seria, porém, esta a rota a seguir.

Um projeto de lei, pois, assim como pode ser iniciado em qualquer das Casas do Congresso, ou pelo Presidente da República, poderia, igualmente, ser iniciado pela plêiade de juristas, sociólogos, economistas, enfim, pelas pessoas de inteligência e cultura aprimoradas, a quem a experiência das coisas da vida houvesse, aperfeiçoando-as, furtado à mera condição de teóricos.

Qualquer projeto de lei, aliás, de iniciativa de uma das parcelas clássicas do Parlamento, ou do Presidente da República, seria, pelo órgão iniciador, apenas formulado em têrmos gerais e não poderia ser submetido à discussão, sem ter sido redigido devidamente, pelo corpo técnico, para que se lhe desse uma base científica e para que se evitassem, desde o início, "incoerência e antinomias berrantes de fundo e de forma, oriundas, precisamente, da falta de conhecimento do direito, de unidade de vistas, de carência de regras gerais".

O poder de exame, pròpriamente dito, o poder de discutir os projetos de lei, porém, pertenceria, apenas, às duas tradicionais Casas do Congresso, não podendo o órgão (ocasionalmente iniciador e sistemàticamente redator) se opor aos mesmos ou se pronunciar sôbre sua conveniência ou impropriedade, ao menos, durante os primeiros tempos de seu funcionamento, porque suas prerrogativas, como as de tôdas as novas instituições, poderiam ser dilatadas ou decrescer, con- 
forme seu aumento de conceito, na opinião pública, ou seu desmere-
cimento. especialistas novamente se faria surante a discussão, a ação dos mesmas.

à redação das

pois que o Poder Legislativo vota e à última - já por si bipartida, vetar - não haveria manifestação o executivo tem a faculdade de pecializada.

A tradicional Inglaterra, consoante ensina JEAN CRUET vida do Direito, pg. 327), reconsonte ensina JEAN CRUET ("A beneficiar-se com a ação eficiente dos eso a imperiosa necessidade de MENTARY COUNSEL'S OFFICE especialistas, criou o PARLIAos "bills" governamentais OFFICE, que tem, por finalidade, redicir be à iniciativa do govêrno a justamente porque, naquele Estado, camente se compreenderá o valor da maioria dos projetos de lei, fàcilque êle deve expressar, perante a da atuação do referido órgão e o. as tramitações de sua imperfeita nações civilizadas, que lutam com

O corpo técnico, a que se relaboração legislativa.

tima análise, uma adaptação re inere o presente estudo, seria, em úllevado à Inglaterra, onde as leis, instituição que tantas vantagens tem características de obscuridade, graças à sua atuação, perderam as. cristalinas, compreensíveis e cientificamo e prolixidade, para serem Apenas, em vez de funcionar jucamente concisas.

Legislativo.

Não se

das comissões parlamentares, para vez, trazendo à baila a capacidade. pecialistas. E', ainda, JEAN para suprir o trabalho dos juristas e esirrespondivelmente:

"Há, fora de

mens eminentes e instruídos, seio das comissões parlamentares, hodessas comissões, permite-lhes mas a composição variável e variada esfôrço persistente necessário antes a troca rápida das idéias que o legislativa e dar, por êste mo para reunir os materiais da elaboração do alicerce das realidades objetivas estabelecimento dum texto, o sóli-

Não avançamos, pois, às exigências de SAINT-GIRONS, queestabelece, de maneira categórica:

"Il faut de jurisconsultes, et seulement des jurisconsultes pour
bien préparer les lois, pour maintenir dans une harmonie, constante et progressive". Manuel de Droit Constitutionnel", pg. 421).

Sem chegarmos, porém, a essas assertivas dogmáticas, em face das próprias realidades da vida e da precariedade das condições ambienciais hodiernas e nacionais, concluímos:

$2 .^{\circ}$ - A elaboração legislativa ,tal como se acha regulamentada atualmente, é, sem contestação possível, falha e incompleta;

$2 .^{\circ}$ - A divisão do trabalho e a especialização de atividades, que se impõem em todos os departamentos da ação humana, são indispensáveis, sobretudo, quando se trata do exercício de funções de relêvo, como são as legislativas;

3. - Uma vez que é inexeqüível a ereção de um Congresso onde prevaleçam os excepcionalmente capazes, homens de inteligência, cultura e ação, torna-se exigível a criação de uma entidade, que apresente componentes com estas condições:

$4 .^{\circ}$ - A nova agremiação técnica será formada por pessoas reconhecidamente competentes, indicadas e nomeadas, em sua grande maioria, pelo Legislativo, pelo Executivo e pelo Judiciário;

$50^{\circ}$ - Um pequeno número de vagas será preenchido por especialistas nomeados, diretamente, pelo próprio órgão que se constituir;

6. - Com a fundação dêste, desaparecerão as malsinadas Comissões Parlamentares, sem que estremeçam, sequer, as bases democráticas, uma vez que serão limitadas suas ações à parte técnica;

7. - Terá funcões circunscritas às atividades pròpriamente legislativas, em sentido amplo, não se imiscuindo nas atividades críticas e políticas, que continuarão pertencendo exclusivamente ao Parlamento;

8. ${ }^{\circ}$ - Ser-lhe-á concedida a iniciativa de projetos de lei, assim como se atribui a mesma às duas Câmaras e ao Presidente da República;

9. - Afora o poder de iniciativa, terá o dever de redigir os projetos de lei, partam êles donde partirem;

$100^{\circ}$ - Finalmente, a agremiação não se imiscuirá nas várias discussões, nem realizará qualquer atividade, quando tiver lugar a deliberação final, cabendo-lhe, porém, a redação das emendas que, porventura, forem oferecidas.

Portanto, na própria conjugação de opiniões, oriundas dos mais diversos países civilizados, e unânimes em condenar o atual processo legislativo; no exemplo da vetusta Inglaterra, criadora, por excelência, do regime representativo e conservadora de belas tradições, que, sem vacilar, soube erigir uma instituição de especialis- 
tas, para interferir na redação das leis; no exame detido das con-
dições sociais dos povos em próprio estudo retrospectivo geral, e, sobretudo, da nossa nação; no anima-nos a sadia convicção de que princio do raciocínio expendido, posto não investe contra os eleva, principalmente, o sistema propugna pelo império absoluto elevados preceitos democráticos, não ressente de inconciliáveis fúrias i uma minoria de técnicos, nem se

\section{RELATÓRIO E PARECER}

\section{Relator: DARCY AZAMBUJA}

A tese tem merecido o estudo de quantos se preocupam com boa organização do regime representativo tos se preocupam com a é uma contribuição original à sua solução, e a perfeição das leis, e A autora acentur

portante dos poderes legislativos noncia, o papel cada vez mais imsa às imperfeições que eivamos nos Estados modernos e depois pasfreqüentemente se promulgam o processo de elaboração das leis, que fundo.

conhecimentos dos má redação, quer também pela deficiência de as leis suscitam muitas vêzes dúviais, por parte de seus autores, deriam ser evitados. Isso se deve

çoã dos parlamentos, que deveriam prossegue a autora, à composijuristas, sociólogos, economistas. Sendo os membros do Poder

políticos, êstes antepõem do Poder Legislativo eleitos pelos partidos às qualidades de saber e experiênciabilidades eleitorais do candiato

Para aperfeiçoar a elaboração dos complexos problemas sociais. que a enfermam, propõe a oração legislativa e escoimá-la dos vícios anexo ao legislativo, que teria po criação de um órgão colegiado, dos projetos de lei, e também o poder de precípua a redação final

Composta exclusivamente o poder de iniciativa dos mesmos. pela Câmara, pelo Senado, pelo homens de cultura, seria eleito e constituiria um corpo coletivo Poder Executivo e por si mesmo, leis, sem tirar a decisão final ao de supervisão na elaboração das

A Comissão decisão final ao Parlamento.

vando sua erudição e finalidade, rente o contexto da tese, e, loute modificação. Entendendo que resolveu aprová-la, com a seguintensa reforma contendendo que sua cabal adoção implicaria exórgão referido deva bas as casas do Congresso, excluindo, pelo regimento de am- jetos de lei, mas atendendo ao objetivo fundamental da louvável inovação.

\section{DEBATES EM PLENÂRIO}

O SR. PRESIDENTE - Júlio Cézar Bonazzola - Está em pauta o "Problema da Elaboração Legislativa", de autoria da ilustre professora Rosah Russomano de Mendonça Lima, sendo relator da tese o eminente professor Darcy Azambuja.

O SR. DARCY AZAMBUJA - Sr. Presidente, se V. Excia. me permite, farei um breve resumo da tese e do parecer apresentado pela Comissão.

A ilustre professora apresenta a tese subordinada ao título "Problema da Elaboração Legislativa". Ela explana com proficiência e apoiada não sòmente em autores, como na observação direta dos fatos, a importância cada vez maior, do Poder Legislativo dos Estados modernos, isto é, a função cada vez mais efetiva e profunda que o Estado exerce através da lei. Ao mesmo tempo, mostra como essa elaboração legislativa, devido a diversas circunstâncias que aponta a seguir, se ressente de vícios e de defeitos que prejudicam e, muitas vêzes, anulam a ação do Estado, que se processa através das leis quer quanto à forma, quer quanto ao fundo, nos Parlamentos modernos. Aliás, como sempre foi, se ressente de vícios, que decorrem, principalmente - segundo o pensamento da autora - em razão da composição dos parlamentos. As leis, visando regular relações oficiais e os interêsses da sociedade deveriam, quer pela forma, quer pelo seu conteúdo intrínseco, atingir diretamente a sua finalidade. No entretanto, os Parlamentos dos Estados modernos, em geral, se compõem, na sua grande maioria, de pessoas que não são juristas, que não têm cultura sociológica, econômica, filosófica necessárias, e que, sobretudo, se deixam levar por interêsses políticos-partidários, de modo que as leis se revestem de graves defeitos, não só na sua redaçã̃o, como quanto ao próprio objetivo dos seus autores, que não têm bastante competência e experiência para elaborar uma lei, no seu verdadeiro sentido.

A seguir, diz a autora, que se deve, em grande parte, êste defeito a que os parlamentos modernos são formados, na sua generalidade por pessoas indicadas pelos partidos políticos, e os partidos políticos não se preocupam precìpuamente com a indicação de indivíduos que se notabilizem pela sua cultura jurídica, sociológica, econômica ou filosófica e, sim pelas suas possibilidades eleitorais. Êste é um mal difìilmente removível, mas seria de todo interessante para a sociedade - ainda é a autora quem o diz - procurar, senão suprimir, pelo menos atenuar êste defeito da elaboração legislativa, propugnando medidas no sentido de que os parlamentos se com-

16 - R. D. - 2. ${ }^{\circ}$ Vol. 
pusessem, pelo menos na sua maioria, de pessoas competentes do ponto de vista intelectual e idôneas do ponto de vista moral.

Depois de várias considerações, ela sugere uma solução original e interessante. Atendendo a que não seria possível modificar tão ràpidamente a mentalidade dós homens, partidos e agremiações que, a exemplo, do que se começou a tentar na Inglaterra, se criasse um órgão anexo aos poderes legislativos, um órgão coletivo, composto exclusivamente de juristas, sociólogos, economistas e pessoas enfim, notáveis pela sua cultura e experiência dos problemas sociais.

Êste órgão coletivo seria eleito, parte pela Câmara, parte pelo Senado, no nosso caso; alguns membros seriam nomeados pelo poder executivo, pelo Presidente da República, e outro eleitos pelo próprio órgão, depois de constituído por esta eleição preliminar, sempre com esta exigência fundamental de que fôsse composto de notabilidades jurídicas, sociológicas ou filosóficas.

Este órgão teria por missão fundamental elaborar os projetos de lei, dar a redação final aos projetos de lei elaborados pelo parlamento para que, pelo menos na sua forma, êles não apresentassem os vícios, defeitos e obscuridades encontrados com muita freqüência nas leis.

Em segundo lugar, aduz, em geral nos parlamentos predominam os interêsses políticos, discussões que muitas vêzes tiram o tempo dos membros do Poder Legislativo para propor projetos de leis inadiáveis. Teria também êsse órgão iniciativa nas leis. Assim como, pelo nosso regime os deputados e senadores, comissóes técnicas de cada Casa Legislativa, ou o presidente da República têm o direito à iniciativa das leis, êsse órgão também o teria.

Mas, sua função fundamental seria exatamente dar redação final a todos os projetos de leis elaborados pelo parlamento, sem intervir nas discussões, sem tirar ao parlamento a decisão final, a última palavra sôbre todos os assuntos.

De sorte, que pareceu à Comissão, que era uma sugestão interessante e original.

No entanto, exatamente por isso, como sua adoção cabal dependeria de uma reforma constitucional, pareceu à Comissão que seria razoável adotar a conclusão da tese com a modificação de que êsse órgão, em vez de só poder ser criado mais tarde em virtude de uma reforma constitucional, o que levantaria controvérsias, poderia ser criado no próprio Regimento Interno do próprio Poder Legislativo, fôsse o Regimento Interno da Câmara, do Senado, das Assembléias estaduais ou das Câmaras municipais, que poderiarn criar êsse órgão exatamente nos têrmos em que a tese o propõe. Naturalmente criado no Regimento Interno, não poderia ter a faculdade de iniciativa, que só a Constituição pode autorizar.
Foi nesse sentido, sr. Presidente, que a Comissão aprovou unanimemente a tese e a submeteu à aprovação do plenário.

O SR. PRESIDENTE - Em meu país o assunto foi tratado pelo mais ilustre civilista dêste século, por Alfredo Colmo. Propôs êle esta mesma idéia faz quase 40 anos, e as objeções que se fizeram foram de duas ordens, quanto ao aspecto teórico e quanto ao aspecto prático.

Quanto ao aspecto teórico, foi objetado que de certo modo havia um princípio de delegação de função pública, o que era perigoso, porque atentava, de certa maneira, contra o princípio de soberania que assim se delegava.

Para obviar essa dificuldade negou-se que a opinião do corpo de letrados tivesse caráter imperativo, que ficaria apenas como um corpo acessório.

Depois, vieram as dificuldades práticas. Todos conhecemos, porque temos vivido um pouco a vida parlamentar, como cada senhor deputado deseja ser soberano em suas idéias, e não se havia de querer submeter.

$\mathrm{Na}$ realidade, a iniciativa não logrou êxito, mas entendo que, realmente, muitas leis não apresentariam os defeitos que possuem, se houvesse um corpo de letrados, de conselheiros que estivesse em condições de contribuir para a melhor elaboração legislativa, integrado por sociólogos, economistas, juristas de nomeada, um verdadeiro corpo técnico, paralelo ao corpo parlamentar, que tivesse caráter decisório.

O SR. DARCY AZAMBUJA - Neste ponto, o Poder Legislativo, nos Estados modernos, está em grande inferioridade em relação ao Executivo, pois êste dispõe de um corpo de técnicos, de órgãos informativos, enquanto que aquêle conta, apenas, com os seus próprios membros.

O SR. CAMILO MARTINS COSTA - Mas nada impede que - Poder Legislativo se enriqueça com a organização dessas Comissões. Nós todos, sob certos aspectos, concordamos com a ilustre autora da tese. Entretanto, frisamos e fazemos algumas restrições quanto à idéia de colocar o Poder Legislativo sob a tutela dêsse óroão, embora no estado em que estamos, não se possa negar que o Poder Legislativo é invadido por elementos que não estão à altura dà delicada tarefa de elaborar e ultimar a lei.

Mas, o que não seria êsse Poder Legislativo quando não tivesse mais essa responsabilidade? Acho que não devemos tirar ao Poder Legislativo a responsabilidade pela feitura das leis, até porque isso serve, enfim, de filtro, digamos, para que êsse Poder Legislativo não seja um desaguadouro de nulidades e de mediocridades. 


$$
-700-
$$

Admito que o Poder Legislativo, que tem o poder regimental, deva' enriquecer sua organização com essas comissões técnicas.

Mas, eu seria intransigentemente contrário à idéia, em razão de uma reforma constitucional, que colocasse o Poder Legislativo sob a tutela de um órgão de correção. Quanto a êste aspecto, data vênia o grande aprêço que tenho à autora da tese, fui intransigentemente contrário. Agora, reconheço a verdade de suas argumentações; reconheço que se possa sugerir ao Poder Legislativo a formação dessas Comissões, que são perfeitamente normais.

Mas, eu preferiria o inconveniente do legislador que não soubesse legislar, do que o inconveniente de que não tivesse nem mais a responsabilidade de legislar, porque aí ficaria pior.

O SR. PRESIDENTE - O problema não seria sòmente regimental, senão legislativo.

O SR. DARCY AZAMBUJA - Bem, ficaria a cargo do próprio Poder Legislativo. Nada impede que a Câmara dos Deputados, amanhã, resolva criar uma Comissão, com cargos remunerados, elementos eleitos por ela, técnicos encarregados da elaboração final das leis.

O Poder Legislativo, rec onhecendo essa necessidade, organizaria essas Comissões técnicas, pois creio que o príncipio de soberania seria resguardado, porque a sua organização competiria ao próprio Poder Legislativo. Assim como compete ao Poder Legislativo a organização de seus serviços. Essas comissões nada mais seriam do que o desdobramento de seus serviços.

O SR. CAMILO MARTINS COSTA - Isto quando faltassem os valores, mas em geral os tem.

O SR. DARCY AZAMBUJA - Seria realmente interessante um órgão criado pelo próprio Poder Legislativo, com essa finalidade.

O SR. CAMILO MARTINS COSTA - Aliás, freqüentemente o faz, convocando técnicos, funcionários especializados, etc.

O SR. DARCY AZAMBUJA - Assim como tem uma Comissão de taquígrafos, poderia ter uma comissão de redatores técnicos. Neste sentido, o Legislativo tem cochilado, porque enquanto o Executivo dispõe dêstes técnicos, destas comissões, de elementos de informações, o Legislativo dispõe só de seus próprios membros, que têm uma série de deveres e responsabilidades outras, e nem sempre podem atender a essa parte. A nossa experiência mostra que são sempre três ou quatro os elementos do Parlamento que se encarregam da redação final das leis, quando não é um só.

O SR. JÚLIO CÉSAR BONAZZOLA - Isşo acontece em todo o mundo.

$$
-701-
$$

O SR DARCY AZAMBUJA - E' verdade que a lei já foi muito o secretário' the dá redação como melhor lhe parece.

de nós sabemos que as comissões de redação . Te reformar uma dispõ pretexto de fazer redação. Não resta dúvida que, depois, a relei, a pretexto de fazer plenário, mas a confiança na comissão dação final é aprovada pelo Plenário, macos, introduzidas a pretexto de de redação é tal que muitas inovaçobidas.

melhorar a redação, passam desperal

O SR. JÚLIO CESAR BONAZZOLA - De qua que merece as o trabalho da dra. Rosah Russomano é uma inicatecupação técnica. nossas felicitações, porque demonstra grande preocupaçassão.

Só há a ser considerado pelo plenário o voto da Con de que êste

O SR. DARCY AZAMBUJA - Que é no sentido de que exte. órgão seja criado pelo próprio Legislativo, no seu regimento conside-

O SR. PRESIDENTE - Se nă 